\title{
IDENTIFIKASI JENIS BAMBU YANG DIMANFAATKAN DI HUTAN TEMBAWANG DUSUN TEKALONG DESA SETIA JAYA KECAMATAN TERIAK KABUPATEN BENGKAYANG
}

\author{
(Identification Of Bamboo Types Used In Tembawang Forest Of Tekalong Village Setia Jaya \\ Subdistrict Teriak Bengkayang District)
}

\section{Katarina Tika, Ratna Herawatiningsih, Lolyta Sisillia}

Fakultas Kehutanan Universitas Tanjungpura. Jalan Daya Nasional Pontianak 78124

Email: Katarinatika97@yahoo.com

\begin{abstract}
Bamboo has been known by people for generations and has good properties to be used. The purpose of this study was to identificated types of bamboo that grow in Tembawang Forest of Tekalong and obtain data on the utilization of bamboo carried out by the people of Tekalong, Setia Jaya Village, Teriak District, Bengkayang Regency. The method used in this study is a survey method. Data collection techniques, with observation and interviews using the help of a questionnaire. Sampling at the research location was done by purposive. The sampling technique for bamboo at the study site was using double plots measuring $5 \mathrm{mx} 5 \mathrm{~m}$. The amount of bamboo found in 4 areas of Tembawang Forest in Tekalong are 6 types of 3 different genera namely the genus Schizostachyum, Gigantochloa and Bambusa. The types of bamboo include: kayan (Schizostachyum flexuosum Widjaja), gare (Schizostachyum brachycladum Kurz), tarenk (Gigantochloa hasskarliana (Kurz) Backer ex Heyne), bangking (Gigantochloa balui K.M. Wong), betung (Gigantochloa levis (Blanco) Merr.), aur (Bambusa vulgaris Schrad ex Wendl). Bamboo in Tekalong can be used as raw material for making handicrafts, traditional ceremonies, making lemang, consumed and other benefits.
\end{abstract}

Keywords :Identification, Bamboo, Utilization, Tembawang Forest

\section{PENDAHULUAN}

Bambu termasuk dalam suku Poaceae, juga dikenal dengan nama Gramineae atau suku rumput-rumputan, bambu mudah sekali dibedakan dengan tumbuhan lainnya, karena tumbuhnya yang merumpun (Yani, 2012). Ciri lain dari bambu adalah memiliki bentuk batang bulat, berlubang di tengah dan beruas-ruas, bentuk percabangan kompleks, setiap daun bertangkai, dan bunganya terdiri dari sekam kelopak dan sekam mahkota serta 3-6 buah benang sari (Widjaja, 2001). Pada tanah yang subur tanaman bambu akan tumbuh dengan baik karena kebutuhan makanan bagi tanaman tersebut akan terpenuhi (Berlian dan Rahayu, 1995).
Semakin hari populasi bambu semakin berkurang karena banyak tempat tumbuh bambu yang dialih fungsikan menjadi lahan perkebunan dan lahan untuk berladang. Peningkatan penggunaan beberapa jenis bambu menyebabkan tanaman bambu terekploitasi secara tidak terkendali tanpa diimbangi dengan tindakan pembudidayaan. Secara ekologi akar rimpang bambu mampu menjaga sistem hidrologis sebagai pengikat tanah dan air, sehingga dapat digunakan sebagai tanaman konservasi (Widnyana, 2012).

Menurut Hartanto (2011) kegunaan dan manfaat bambu bervariasi mulai dari perabotan rumah, perabotan dapur dan kerajinan, bahan bangunan serta peralatan lainnya dari yang sederhana sampai 
dengan industri bambu lapis, laminasi bambu, maupun industri kertas yang sudah modern. Bambu dikenal oleh masyarakat memiliki sifat-sifat yang baik untuk dimanfaatkan antara lain: batangnya kuat, lurus, rata, keras, mudah dibelah, mudah dibentuk, dan mudah dikerjakan serta mudah diangkut. Selain itu bambu juga relatif murah dibanding bahan bangunan lain karena banyak ditemukan di sekitar pemukiman pedesaan (Sinyo et al, 2017).

Secara turun temurun masyarakat di Dusun Tekalong Desa Setia Jaya Kecamatan Teriak Kabupaten Bengkayang telah lama mengenal bambu dan memanfaatkannya sebagai bahan baku kerajinan tangan dengan cara menganyam untuk dipakai sendiri atau dijual. Selain untuk kerajinan, bambu yang masih muda (rebung) juga dimanfaatkan sebagai bahan pangan untuk di konsumsi oleh masyarakat. Tanaman bambu didapat dari Hutan Tembawang atau di luar areal Hutan Tembawang. Banyaknya jenis bambu yang terdapat di Hutan Tembawang Dusun Tekalong, masih belum diketahui jenisnya, maka perlu dilakukan identifikasi jenis-jenis bambu tersebut dan bentuk pemanfaatan bambu yang dihasilkan oleh masyarakat Dusun Tekalong. Penelitian ini bertujuan untuk mendapatkan data identifikasi jenis bambu yang tumbuh di Dusun Tekalong dan mendapatkan pemanfaatan bambu yang dilakukan oleh masyarakat Dusun Tekalong Desa Setia Jaya Kecamatan Teriak Kabupaten Bengkayang.

\section{METODE PENELITIAN}

Penelitian ini dilakukan di Dusun Tekalong Desa Setia Jaya Kecamatan
Teriak Kabupaten Bengkayang. Penelitian dilaksanakan selama kurang lebih 4 minggu mulai tanggal 31 Agustus sampai dengan tanggal 28 September 2019 di lapangan dilanjutkan dengan analisis data penelitian. Alat yang digunakan antara lain peta lokasi, GPS, kompas, tali rafia, kamera, kuesioner, alat perekam, tally sheet, peralatan herbarium seperti : koran, gunting, parang, spirtus, spidol, sasak, isolatif, strerefoam, plastik packing, label. Objek penelitian ini adalah semua jenis bambu dan masyarakat yang memanfaatkan bambu di Dusun Tekalong Desa Setia Jaya Kecamatan Teriak Kabupaten Bengkayang. Metode yang digunakan dalam penelitian ini adalah metode survey dengan teknik pengumpulan data secara observasi dan wawancara menggunakan bantuan kuesioner. Pengambilan sampel responden dilakukan secara purposive, dimana peneliti secara sengaja menentukan responden yang akan dipilih dengan cara menetapkan ciri-ciri khusus yang sesuai dengan tujuan penelitian (Junisa, 2019). Proses identifikasi dilakukan langsung di hutan tembawang menggunakan bantuan kunci determinasi. Teknik pengambilan sampel bambu di lokasi penelitian menggunakan petak ganda berukuran $5 \mathrm{~m}$ $\times 5 \mathrm{~m}$, dengan jumlah petak penelitian sebanyak 50 buah. Luas areal masingmasing tembawang \pm 2 Ha sehingga luas areal sampel penelitian 0,125 Ha.

HASIL DAN PEMBAHASAN

Jenis Bambu yang Ditemukan

Penelitian yang telah dilaksanakan di Hutan Tembawang Dusun Tekalong Desa Setia Jaya Kecamatan Teriak Kabupaten 
Bengkayang pada 4 lokasi tembawang. Secara keseluruhan hasil identifikasi di lapangan ditemukan ada 6 jenis bambu dari 3 genus yang berbeda yaitu genus Bambusa, Gigantochloa dan Schizostachyum. Penelitian yang dilakukan oleh Sary (2018) di Hutan Tembawang Desa Suka Maju Kecamatan Sungai Betung ditemukan sebanyak 4 jenis dari 3 genus yaitu Dendrocalamus asper (Bambu Betung), Gigantochloa apus (Bambu Tali), Schizostzchyum zollingeri Steud (Bambu Buluh), dan Schizostzchyum sp (Bambu Munti), dimana dari 4 jenis bambu tersebut berbeda jenis dengan bambu yang ditemukan di Dusun Tekalong. Secara lengkap jenis bambu yang ditemukan dapat dilihat pada Tabel 1.

Tabel 1. Rekapitulasi Jenis Bambu yang Ditemukan di 4 Areal Tembawang (Recapitulation of Bamboo Types Found in 4 Tembawang Areas)

\begin{tabular}{|c|c|c|c|c|}
\hline No & Nama Lokal & Nama Latin & $\begin{array}{c}\text { Jumlah } \\
\text { Petak }\end{array}$ & $\begin{array}{c}\text { Jumlah } \\
\text { Individu }\end{array}$ \\
\hline 1 & Kayan & Schizostachyum flexuosum Widjaja & 8 & 18 \\
\hline 2 & Gare & $\begin{array}{l}\text { Schizostachyum brachycladum } \\
\text { Kurz }\end{array}$ & 6 & 9 \\
\hline 3 & Tarenk & $\begin{array}{l}\text { Gigantochloa hasskarliana (Kurz) } \\
\text { Backer ex Heyne }\end{array}$ & 13 & 21 \\
\hline 4 & Bangking & Gigantochloa balui K.M. Wong & 9 & 11 \\
\hline 5 & Betung & Gigantochloa levis (Blanco) Merr. & 9 & 11 \\
\hline 6 & Aur & Bambusa vulgaris Schrad ex Wendl & 5 & 6 \\
\hline & Total & & 50 & 76 \\
\hline
\end{tabular}

\section{Identifikasi Jenis Bambu}

Adapun jenis bambu yang ditemukan pada Hutan Tembawang Dusun Tekalong Desa Setia Jaya Kecamatan Teriak Kabupaten Bengkayang adalah sebagai berikut :

\section{Kayan (Schizostachyum flexuosum Widjaja)}

Bambu Kayan memiliki tipe rumpun simpodial, tegak dan padat tetapi ada juga yang kurang padat, rebung berwarna hijau yang tertutup bulu berwarna coklat. Percabangan tumbuh jauh dari permukaan tanah, cabang sama besar dengan cabang lainnya dengan ujung melengkung. Buluh tingginya mencapai $15 \mathrm{~m}$ dan tegak, memiliki batang berwarna hijau terang atau hijau tua, panjang ruas antara 55-75 cm, dengan diameter 1-4 $\mathrm{cm}$. Pelepah buluh tidak mudah luruh, tertutup bulu halus berwarna coklat hingga kehitaman, dengan panjang bulu kejur sekitar $10 \mathrm{~mm}$, kuping pelepah buluh membulat. Daun berwarna hijau, runcing, dengan kuping pelepah daun melengkung keluar dan ada beberapa bulu kejur (Gambar 1). Menurut Widjaja (2001) tipe rumpun simpodial, padat dan tegak. Rebung berwarna hijau, dengan bulu berwarna coklat terang yang besar. Batang sampai setinggi $\pm 15 \mathrm{~m}$. Pelepah buluh berbulu halus, ruas panjang $60-80 \mathrm{~cm}$ dengan diameter 2-4 cm, kuping pelepah buluh membulat dengan bulu kejur kira-kira 3 
mm. Daun runcing, kuping pelepah

panjangnya 5-12 $\mathrm{mm}$.

daun melengkung keluar, berbulu kejur
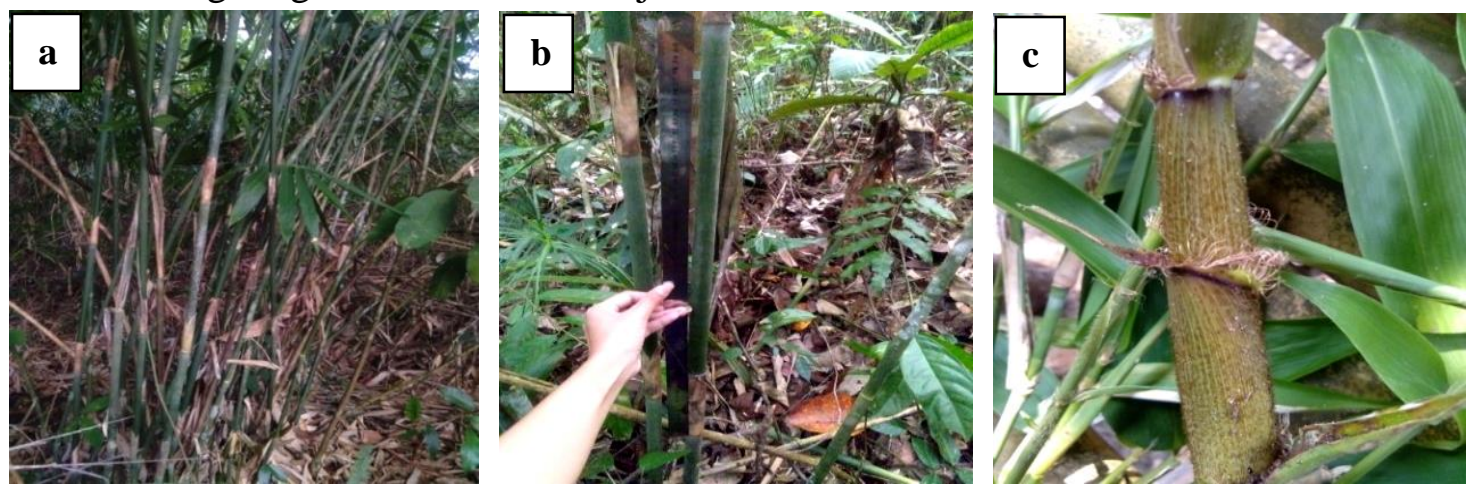

Gambar 1. Bambu Kayan (Schizostachyum flexuosum Widjaja) (Kayan Bamboo (Schizostachyum flexuosum Widjaja)) ket : a. Rumpun b. Batang c. Rebung

\section{Gare (Schizostachyum brachycladum Kurz)}

Bambu Gare memiliki rumpun yang simpodial dan tegak. Rebung berwarna kuning, daun pelepah buluh coklat tertutup bulu coklat. Tinggi buluh mencapai $15 \mathrm{~m}$, ujung melengkung dan tegak. Percabangan sama besar antara cabang satu dan cabang lainnya. Buluh muda tertutup bulu putih yang tersebar, ketika sudah tua bulu tersebut akan gugur dan gundul, berwarna hijau, panjang ruas 35- $60 \mathrm{~cm}$, dengan diameter $7-11 \mathrm{~cm}$. Pelepah buluh tertutup bulu berwarna coklat, tidak mudah luruh, kuping pelepah buluh kecil tingginya 5 mm dengan bulu kejur yang panjangnya sekitar $4 \mathrm{~mm}$, daun pelepah buluh tegak, menyegitiga dengan pangkal yang melebar. Daun pada permukaan bawah agak berbulu, dan ketika tua gundul, kuping pelepah buluh kecil dengan tinggi $1 \mathrm{~mm}$ dan bulu kejur yang panjangnya 6 mm (Gambar 2). Menurut Widjaja (2001) tipe rumpun simpodial, padat dan tegak. Rebung kuning atau hijau, daun pelepah buluh coklat tertutup bulu coklat. Buluh tingginya mencapai 8-15 m, tegak ujungnya melengkung. Percabangan 1,5 m diatas permukaan tanah, cabang sama besar. Buluh muda tertutup bulu putih tersebar, ketika tua akan gugur dan gundul, berwarna hijau atau kuning, ruas panjangnya $35-50 \mathrm{~cm}$, diameternya 8-10 $\mathrm{cm}$. Pelepah buluh tertutup bulu coklat, tidak mudah luruh, kuping pelepah buluh kecil seperti bingkai dan kecil tingginya 2,5-6 mm dengan panjang bulu kejur 4-8 $\mathrm{mm}$, daun pelepah buluh tegak, menyegitiga dengan pangkal melebar. 

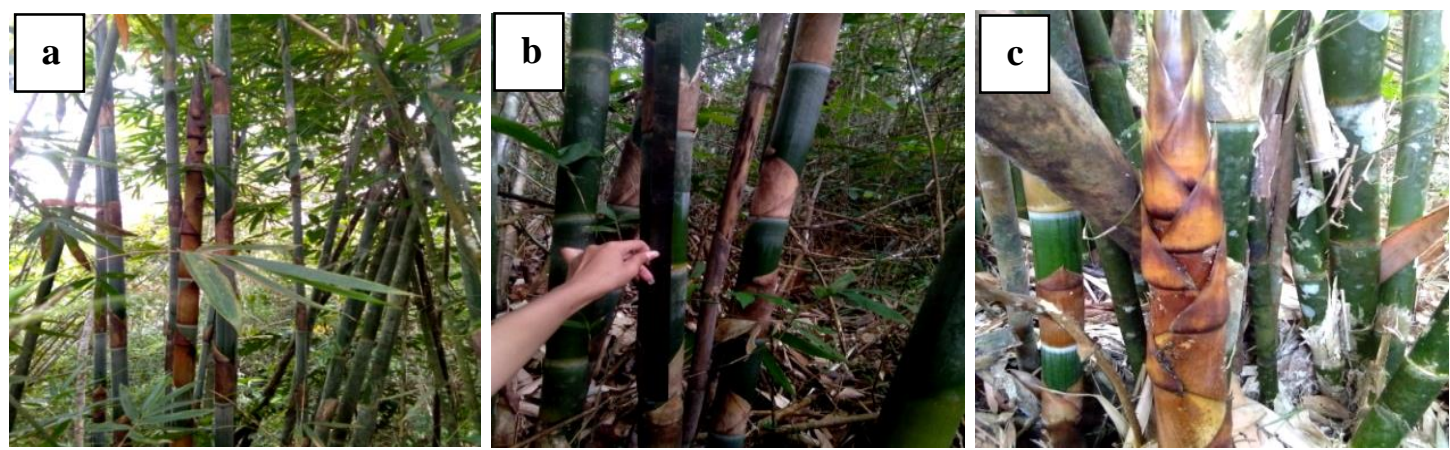

Gambar 2. Bambu Gare (Schizostachyum brachycladum Kurz) (Gare Bamboo (Schizostachyum brachycladum Kurz)) ket : a. Rumpun b. Batang c. Rebung

\section{Tarenk (Gigantochloa hasskarliana (Kurz) Backer ex Heyne)}

Bambu Tarenk memiliki rumpun simpodial,dan tegak. Rebung berwarna hijau, tertutup bulu hitam. Tinggi buluh mencapai $10 \mathrm{~m}$ dan tegak. Percabangan tumbuh jauh dari permukaan tanah, satu cabang lebih besar daripada cabang lainnya, ujungnya melengkung. Buluh muda dengan bulu hitam sampai coklat, gundul ketika sudah tua dan berwarna hijau, memiliki panjang ruas antara 28$50 \mathrm{~cm}$, dengan diameter 4-6 cm. Pelepah buluh tertutup bulu hitam, mudah luruh, tinggi kuping pelepah buluh $3 \mathrm{~mm}$ dan gundul yang diakhiri oleh apendiks (perpanjangan dari pelepah di bagian ujung tepi atas setelah kuping pelepah buluh), dengan bulu kejur pendek, daun pelepah buluh terkeluk balik, menyegitiga dengan pangkal mengecil. Daun bambu ini gundul, kuping pelepah buluh kecil tingginya $1 \mathrm{~mm}$, dengan bulu kejur yang pendek (Gambar 3). Menurut Widjaja (2001) rumpun simpodial, padat dan tegak. Rebung hijau, tertutup bulu coklat dan hitam. Buluh tingginy $10 \mathrm{~m}$, tegak. Percabangan terdapat jauh di permukaan tanah, satu cabang lebih besar dari cabang lainnya, ujung melengkung. Buluh muda dengan bulu hitam sampai coklat, gundul ketika tua dan berwarna hijau, ruas panjangnya 27-51 cm, dengan diameter 3-6 cm. Pelepah buluh tertutup bulu hitam sampai coklat, mudah luruh, kuping pelepah seperti bingkai tinggi $3 \mathrm{~mm}$, gundul yang diakhiri dengan apendiks (perpanjangan dari pelepah di bagian ujung tepi atas setelah kuping pelepah buluh) yang melengkung ke dalam, dengan bulu kejur pendek; daun pelepah buluh terkeluk balik, menyegitiga dengan pangkal mengecil. Daun gundul; kuping pelepah buluh kecil tinggi $1 \mathrm{~mm}$ dengan bulu kejur pendek. 

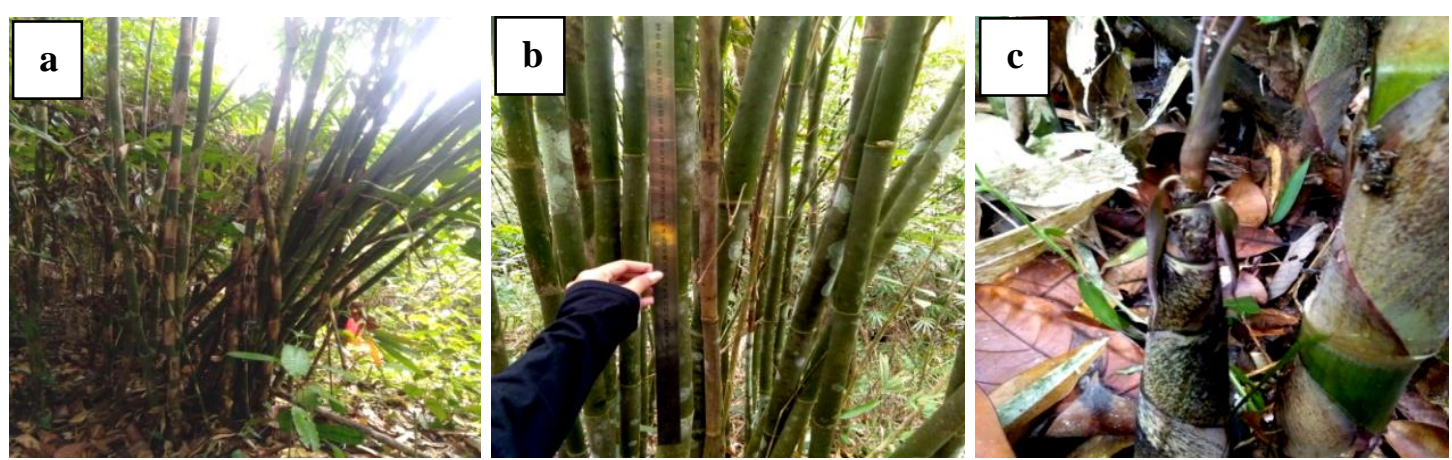

Gambar 3. Bambu Tarenk (Gigantochloa hasskarliana (Kurz) Backer ex Heyne)

(Tarenk Bamboo (Gigantochloa hasskarliana (Kurz) Backer ex Heyne))

Ket : a. Rumpun b. Batang c. Rebung

\section{Bangking (Gigantochloa balui K.M. Wong)}

Bambu Bangking memiliki rumpun simpodial, tegak dan rapat. Rebung berwarna hijau yang tertutup bulu putih dipermukaannya. Buluh tingginya mencapai $12 \mathrm{~m}$ dan tegak. Percabangan tumbuh jauh dari permukaan tanah, salah satu cabang lebih besar daripada cabang lainnya, dengan ujung yang melengkung. Buluh muda tertutup bulu putih dan gundul ketika tua, berwarna hijau atau hijau dengan garis kuning pada batangnya, ruas panjangnya mencapai 34-40 cm, dengan diameter 3$8 \mathrm{~cm}$. Pelepah buluh tertutup bulu putih, dan mudah luruh, tinggi kuping pelepah buluh 2,5 mm, gundul dengan panjang bulu kejur mencapai $4 \mathrm{~mm}$, daun pelepah buluh terkeluk balik, menyegitiga dengan pangkal sempit. Daun bambu ini berwarna hijau memiliki permukaan bagian bawah agak berbulu, kuping pelepah buluh kecil, dengan beberapa bulu kejur dan panjang mencapai $7 \mathrm{~mm}$ (Gambar 4). Menurut Widjaja (2001) rumpun simpodial, padat dan tegak. Rebung kuning hingga hijau yang tertutup bulu putih. Buluh tinggi mencapai $12 \mathrm{~m}$ dan tegak. Percabangan terdapat jauh di permukaan tanah, satu cabang lebih besar daripada cabang lainnya, ujung melengkung. Buluh tertutup bulu putih, gundul ketika tua dan berwarna hijau, atau hijau dengan garis kuning pada pangkalnya, ruas panjangnya mencapai $40 \mathrm{~cm}$, dengan diameter $3-8 \mathrm{~cm}$. Pelepah buluh tertutup bulu putih, dan mudah luruh, kuping pelepah buluh seperti bingkai tinggi $2,5 \mathrm{~mm}$, gundul, dengan panjang bulu kejur mencapai 5 $\mathrm{mm}$; daun pelepah terkeluk balik, menyegitiga dengan pangkal sempit. Daun permukaan bagian bawah agak berbulu, kuping pelepah buluh kecil 1 mm dengan dengan beberapa bulu kejur dan panjang mencapai $7 \mathrm{~mm}$. 

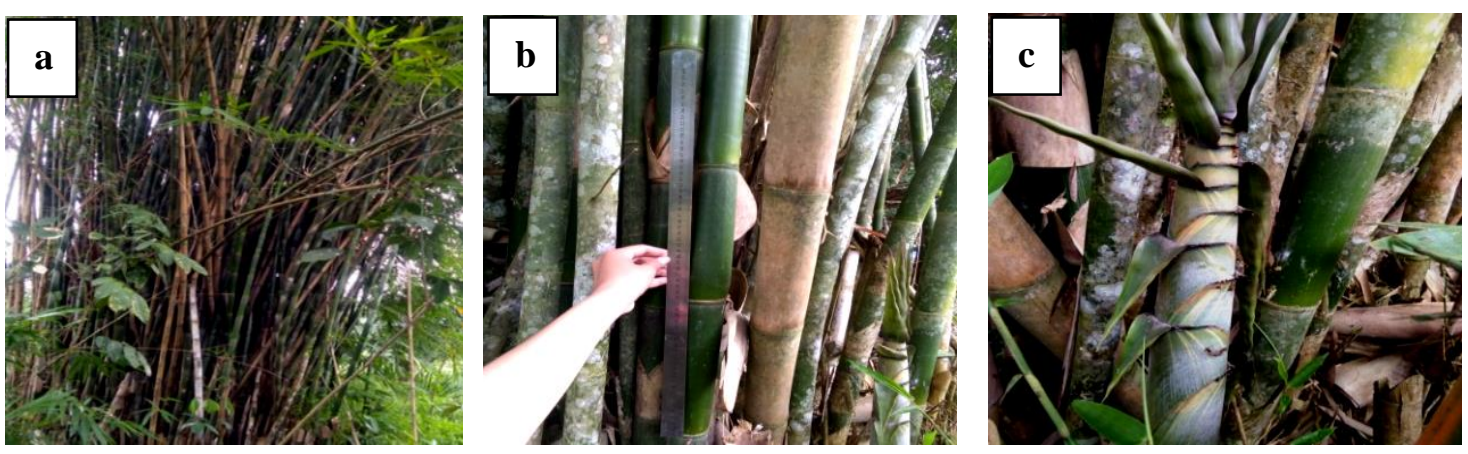

Gambar 4. Bambu Bangking (Gigantochloa balui K.M. Wong) (Bangking Bamboo

(Gigantochloa balui K.M. Wong)) ket : a. Rumpun b. Batang c. Rebung

\section{Betung (Gigantochloa levis}

(Blanco) Merr.)

Bambu Betung memiliki rumpun simpodial, tegak dan rapat. Rebung berwarna coklat atau hitam keunguan, tertutup bulu coklat hingga kehitaman. Tinggi buluh mencapai $20 \mathrm{~m}$, tegak dan ujung melengkung. Percabangan satu lebih besar dari cabang lainnya. Buluh muda tertutup bulu coklat yang tersebar, ketika sudah tua akan gugur dan gundul berwarna hijau atau agak keabu-abuan dan bertotol putih karena ada lumut ketika buluh sudah tua, panjang ruas sekitar 35-55 cm dengan diameter 8-12 $\mathrm{cm}$. Pelepah buluh tertutup bulu coklat hingga hitam, mudah luruh, tinggi kuping pelepah $3 \mathrm{~cm}$ dengan bulu kejur mencapai $10 \mathrm{~mm}$, daun pelepah buluh terkeluk balik. Daun berwarna hijau
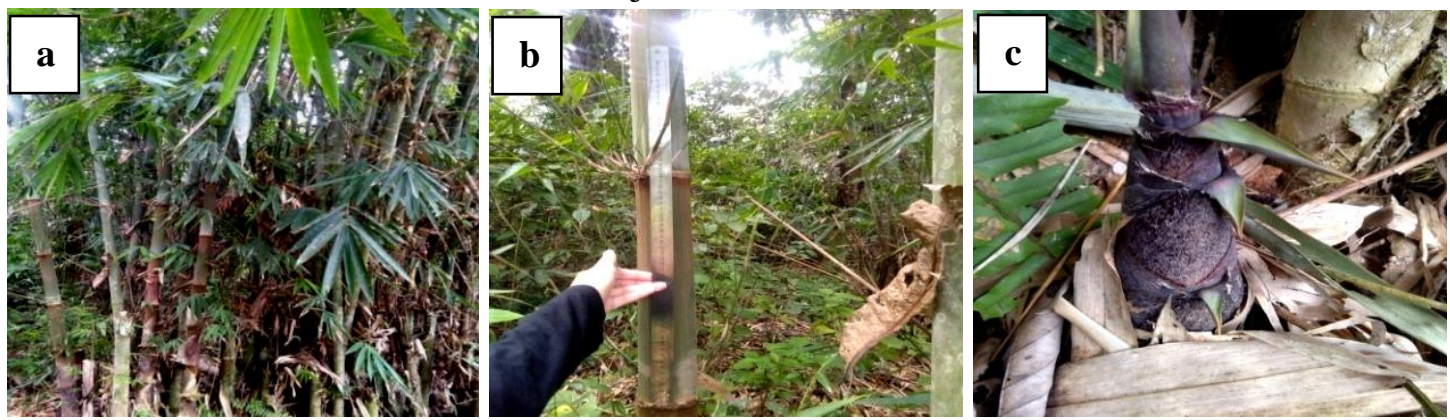

Gambar 5. Bambu Betung (Gigantochloa levis (Blanco) Merr.) (Betung Bamboo (Gigantochloa levis (Blanco) Merr.)) ket : a. Rumpun b. Batang c. Rebung kuping pelepah daun kecil dengan bulu kejur. Menurut Widjaja (2001) tipe rumpun simpodial, padat dan tegak. Rebung ditutupi dengan bulu coklat gelap. Buluh tingginya 15-20 m dengan panjang ruas $30-40 \mathrm{~cm}$, ditutupi bulu coklat ketika muda menjadi gundul ketika tua, berwarna hijau muda hingga hijau keabu-abuan (karena pertumbuhan). Cabang satu lebih besar dari cabang lainnya, pendek dan berbulu, batang ditutupi dengan bulu coklat gelap. Pelepah buluh berbulu hitam, kuping pelepah buluh membulat tegak sampai $3 \mathrm{~mm}$ dengan tinggi bulu kejur mencapai $15 \mathrm{~mm}$, daun pelepah buluh terkeluk balik. Daun melanset, kuping pelepah daun kecil dengan bulu kejur. 


\section{Aur (Bambusa vulgaris Schrad ex Wendl)}

Bambu Aur memiliki rumpun simpodial, tegak dan tidak terlalu rapat. Rebung berwarna kuning atau hijau tertutup bulu coklat hingga hitam. Tinggi buluh mencapai $20 \mathrm{~m}$, agak berbiku-biku dan tegak. Percabangan bambu sekitar 1,5 $\mathrm{m}$ dari permukaan tanah, salah satu cabang lebih besar daripada cabang lainnya. Buluh muda hijau mengkilap, panjang ruas 21-45 $\mathrm{cm}$, dengan diameter 5-10 cm. Pelepah buluh mudah luruh, tertutup bulu hitam hingga coklat tua, kuping pelepah membulat dengan ujung melengkung keluar, tinggi $1 \mathrm{~cm}$ dengan bulu kejur mencapai $6 \mathrm{~cm}$, daun pelepah buluh tegak, menyegitiga dengan bagian pangkal yang melebar. Daun bambu ini gundul, kuping pelepah buluh kecil, tinggi $1 \mathrm{~mm}$ dengan bulu kejur yang pendek (Gambar 6). Menurut Widjaja
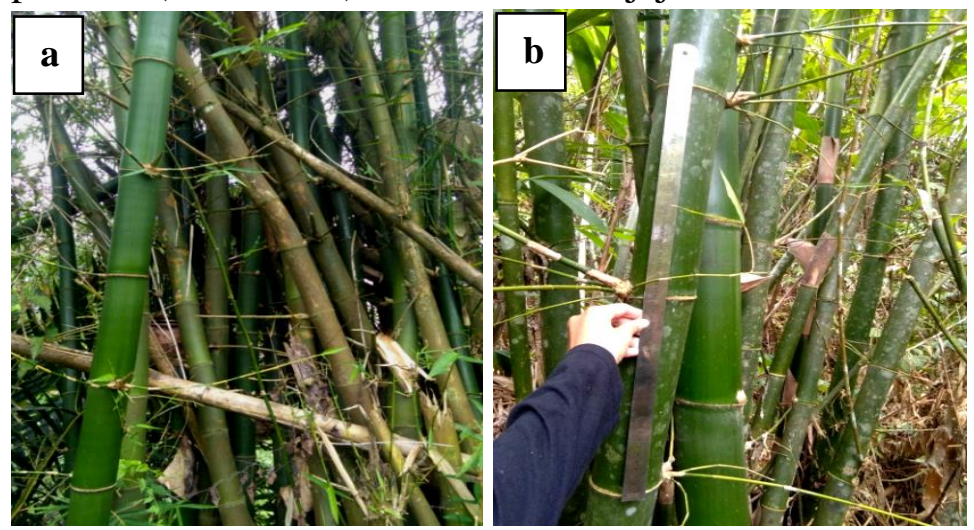

(2001) rumpun simpodial, tumbuh tegak dan tidak terlalu rapat. Rebung kuning atau hijau tertutup bulu coklat hingga hitam. Buluh tingginya mencapai $20 \mathrm{~m}$, tegak atau tegak berbiku-biku. Percabangan tumbuh $1,5 \mathrm{~m}$ diatas perukaan tanah, setiap ruas terdiri atas 2-5 cabang dengan satu cabang lebih besar daripada cabang lainnya. Buluh muda hijau mengkilap atau kuning bergaris-garis hijau; ruas pajangnya mencapai 20-45 cm dengan diameter5$10 \mathrm{~cm}$. Pelepah buluh mudah luruh, tertutup bulu hitam atau coklat tua, kuping pelepah buluh membulat dengan ujung melengkung keluar dengan tinggi 1-1,5 cm dan bulu kejur mencapai 7 $\mathrm{mm}$; daun pelepah buluh tegak, menyegitiga dengan bagian pangkal melebar. Daun gundul, kuping pelepah buluh kecil tinggi $1 \mathrm{~mm}$ dengan bulu kejur yang pendek.

Gambar 6. Bambu Aur (Gigantochloa levis (Blanco) Merr.) (Aur Bamboo Gigantochloa levis (Blanco) Merr.)) ket : a. Rumpun b. Batang c. Rebung

\section{Pemanfaatan Jenis Bambu}

Masyarakat Dusun Tekalong memanfaatkan semua jenis bambu yang terdapat di hutan tembawang. Jenis bambu yang paling banyak dimanfaatkan adalah bambu kayan sering digunakan masyarakat untuk membuat berbagai macam bentuk anyaman. Penelitian yang dilakukan oleh Junisa (2019) di Desa Tanjung 
menemukan ada 10 jenis bambu yang dimanfaatkan oleh masyarakat, sedangkan di Dusun Tekalong hanya menemukan 6 jenis bambu yang dimanfaatkan oleh masyarakat. Hal ini bisa jadi karena penelitian yang dilakukan hanya skala Dusun jadi kawasannya lebih kecil daripada skala Desa. Pemanfaatan bambu sendiri dapat dilihat pada Tabel 2.

Tabel 2. Pemanfaatan Jenis Bambu (Utilization of Bamboo Types)

\begin{tabular}{|c|c|c|c|c|c|c|c|}
\hline \multirow[t]{2}{*}{ No. } & \multirow{2}{*}{$\begin{array}{l}\text { Nama } \\
\text { Lokal }\end{array}$} & \multirow[t]{2}{*}{ Nama Latin } & \multicolumn{3}{|c|}{ Bagian yang di manfaatkan } & \multirow[t]{2}{*}{ Penggunaan } & \multirow{2}{*}{$\begin{array}{c}\text { Bentuk } \\
\text { Pemanfaatan }\end{array}$} \\
\hline & & & Akar & Batang & Daun Tunas & & \\
\hline 1 & Kayan & $\begin{array}{l}\text { Schizostachyum } \\
\text { flexuosum Widjaja }\end{array}$ & & $\sqrt{ }$ & & Kerajinan & $\begin{array}{l}\text { Sikup, nyiru, } \\
\text { nyarang, } \\
\text { ayakan dan } \\
\text { bakul }\end{array}$ \\
\hline 2 & Gare & $\begin{array}{l}\text { Schizostachyum } \\
\text { brachycladum Kurz }\end{array}$ & & $\sqrt{ }$ & & $\begin{array}{l}\text { Konsumsi, } \\
\text { Upacara } \\
\text { adat }\end{array}$ & $\begin{array}{l}\text { Lemang, } \\
\text { cangkang } \\
\text { telur, } \\
\text { cangkang } \\
\text { mangkok, } \\
\text { cangkang } \\
\text { tempayan }\end{array}$ \\
\hline 3 & Tarenk & $\begin{array}{l}\text { Gigantochloa } \\
\text { hasskarliana } \\
\text { (Kurz) Backer ex } \\
\text { Heyne }\end{array}$ & & $\sqrt{ }$ & $\sqrt{ }$ & $\begin{array}{l}\text { Upacara } \\
\text { adat, } \\
\text { konsumsi, } \\
\text { manfaat } \\
\text { Lain }\end{array}$ & $\begin{array}{l}\text { Kalangkang, } \\
\text { rebung, pante, } \\
\text { pagar kebun, }\end{array}$ \\
\hline 4 & Bangking & $\begin{array}{l}\text { Gigantochloa balui } \\
\text { K.M. Wong }\end{array}$ & & $\sqrt{ }$ & & $\begin{array}{l}\text { Kerajinan, } \\
\text { manfaat } \\
\text { lain }\end{array}$ & $\begin{array}{l}\text { Takin, tarinak, } \\
\text { jangkeng, } \\
\text { jemuran }\end{array}$ \\
\hline 5 & Betung & $\begin{array}{l}\text { Gigantochloa levis } \\
\text { (Blanco) Merr. }\end{array}$ & & & $\sqrt{ }$ & Konsumsi & Rebung \\
\hline 6 & Aur & $\begin{array}{l}\text { Bambusa vulgaris } \\
\text { Schrad ex Wendl }\end{array}$ & & $\sqrt{ }$ & & $\begin{array}{l}\text { Manfaat } \\
\text { lain }\end{array}$ & Jembatan \\
\hline
\end{tabular}




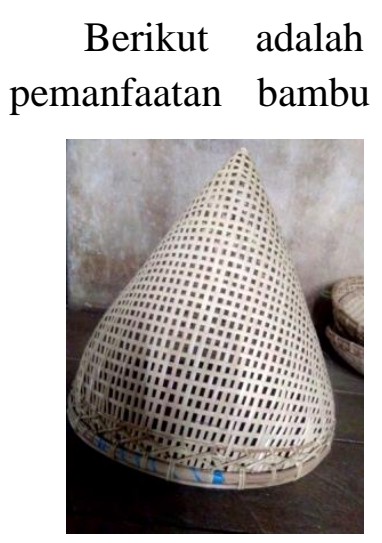

a.Sikup

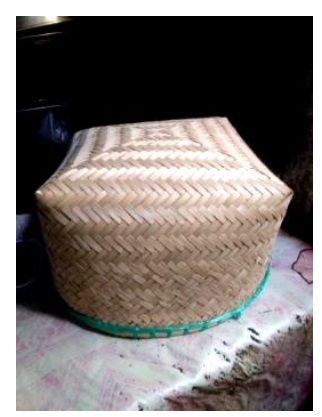

e. Bakul beberapa hasil yang dilakukan

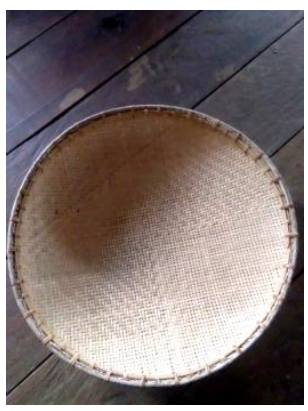

b.Nyiru

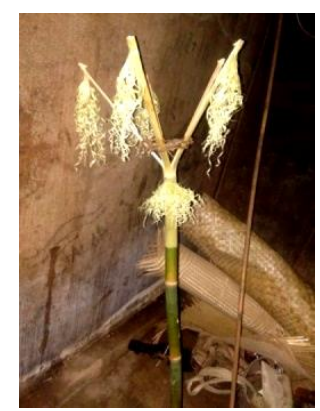

f. Kalangkang

oleh masyarakat Dusun Tekalong dapat dilihat pada Gambar 7.

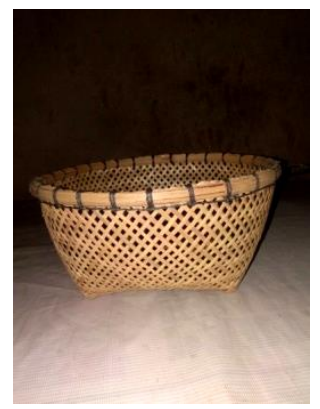

c. Nyarang

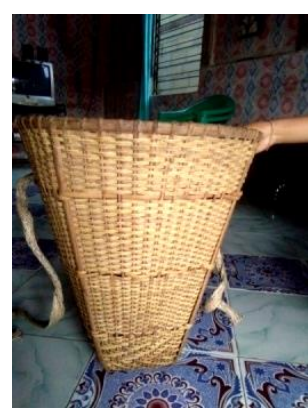

g. Takin

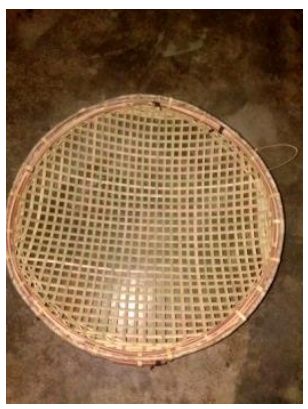

d. Ayakan

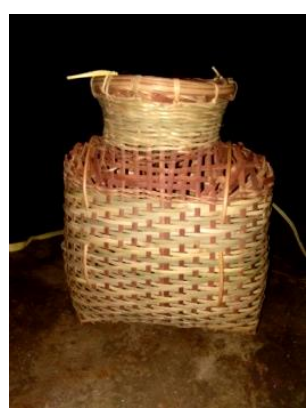

h. Jangkeng

Gambar 7. Hasil Pemanfaatan Bambu (The results of using bamboo)

Pemanfaatan bambu oleh masyarakat Dusun Tekalong telah dilakukan sejak dahulu secara turun temurun. Jenis-jenis bambu tumbuh secara liar di dalam hutan sehingga masyarakat tidak membudidayakan bambu tersebut. Hasil dari kerajinan bambu bisanya dipakai sendiri dan juga untuk dijual jika ada yang memesan. Jenis bambu yang paling banyak dimanfaatkan oleh masyarakat Dusun Tekalong adalah bambu kayan yang menghasilkan berbagai macam anyaman seperti sikup, nyiru, nyarang, ayakan dan bakul. Cara pengolahan bambu tersebut dimulai dari penebangan bambu yang sedang, artinya tidak terlalu tua dan juga tidak terlalu muda, jika bambu terlalu tua maka akan susah dalam proses memisahkan antara kulit luar dan bagian dalam bambu, kemudian bambu dipotong dan dibelah setelah itu dijemur selama 3-5 hari untuk menghilangkan kadar air yang terdapat di dalam batang bambu, kemudian jika sudah kering baru di raut dan dijadikan anyaman.

Pemanfaatan bambu tarenk oleh masyarakat setempat menghasilkan berbagai macam bentuk pemanfaatan seperti untuk keperluan upacara adat yaitu pembuatan kalangkang, membuat pante (tempat untuk menjemur padi), pagar kebun, dan juga rebung yang bisa dikonsumsi oleh masyarakat. Pengolahan bambu tarenk dalam proses pembuatan kalangkang cukup mengambil bagian batang kemudian dibelah dan diraut, 
sedangkan untuk mengolah rebungnya hanya membersihkan kulitnya dan miangnya kemudian dicuci dan dimasak. Hasil pemanfaatan dari bambu bangking juga dapat menghasilkan beberapa anyaman seperti takin, tarinak, jangkeng, juga di manfaatkan sebagai jemuran. Proses pengolahannya hampir sama dengan pengolahan bambu kayan. Bambu gare dimanfaatkan masyarakat untuk upacara adat seperti cangkang mangkok, cangkang telur, cangkang tempayan dan membuat lemang. Lemang sendiri merupakan makanan yang jarang ditemui pada hari biasa dan dibuat pada hari tertentu seperti gawai dan acara lainnya. Proses pengolahannya sangat mudah cukup mengambil batang bambu kemudian dipotong dan bagian atasnya diratakan. Bambu betung dimanfaatkan masyarakat Dusun Tekalong sebagai sayur untuk dikonsumsi dengan cara mengambil rebungnya kemudian membersihkannya dari kulit dan miangnya setelah itu dicuci dan siap dimasak. Bambu aur dimanfaatkan masyarakat sebagai jembatan karena batangnya yang licin tidak ada bulu pada permukaan batang dan dinilai lebih kuat serta diameter yang besar.

Secara keseluruhan bagian dari tanaman bambu yang paling banyak dimanfaatkan oleh masyarakat di Dusun Tekalong adalah bagian batang, dimana hasil dari bambu tersebut dapat menjadi berbagai macam bentuk olahan seperti kerajinan anyaman, keperluan upacara adat, untuk membuat lemang, dikonsumsi dan manfaat lainnya. Penelitian ini serupa dengan hasil penelitian Jong (2018) yang mengatakan rata-rata bagian-bagian bambu yang digunakan oleh masyarakat di Dusun Perigi Desa Semade adalah bagian batang digunakan untuk bahan baku anyaman, tunas dimanfaatkan sebagai bahan pangan atau sayur dan daun digunakan untuk upacara adat.

Pemanfaatan bambu di Dusun Tekalong menghasilkan ada 8 macam bentuk kerajinan, 2 macam pemanfaatan bentuk konsumsi, ritual adat 3 macam pemanfaatan, dan manfaat lain 3 macam pemanfaatan. Hasil pemanfaatan ini lebih sedikit dibandingkan dengan hasil penelitian yang dilakukan oleh junisa (2019) tentang pemanfaatan jenis bambu di Desa Tanjung yang menghasilkan: kerajinan ada 13 bentuk pemanfaatan, konsumsi 3 macam pemanfaatan, ritual adat 7 macam pemanfaatan, obat 2 macam pemanfaatan dan alat bertani ada 15 macam pemanfaatan. Beberapa dari bentuk pemanfaatan bambu di Desa Tanjung dan di Dusun Tekalong memiliki kesamaan namun berbeda nama di masing-masing daerah, seperti sikup, takin, ragak/nyarang, rebung, lemang, cangkang telur, cangkang mangkok. Hasil dari penelitian berarti bagian batang adalah bagian yang sering digunakan atau dimanfaatkan baik untuk anyaman maupun keperluan lain seperti upacara adat, jemuran, pagar kebun dan lain-lain.

\section{Kesimpulan}

Hasil penelitian identifikasi jenis bambu yang dimanfaatkan di Hutan Tembawang Dusun Tekalong Desa Setia Jaya Kabupaten Bengkayang menunjukan bahwa : 
1. Terdapat 6 jenis bambu yang dimanfaatkan oleh masyarakat di Dusun Tekalong yaitu bambu kayan (Schizostachyum flexuosum Widjaja), gare (Schizostachyum brachycladum Kurz), tarenk (Gigantochloa hasskarliana (Kurz) Backer ex Heyne), bangking (Gigantochloa balui K.M. Wong), betung (Gigantochloa levis (Blanco) Merr.) dan aur (Bambusa vulgaris Schraad ex Wendl).

2. Bambu di Dusun Tekalong dapat dijadikan sebagai bahan baku membuat kerajinan, upacara adat, membuat lemang, dikonsumsi dan manfaat lainnya.

3. Bentuk pemanfaatan bambu di Dusun Tekalong antara lain: sikup, nyiru, nyarang, ayakan, bakul, takin, tarinak, jangkeng, kalangkang, cangkang telur, cangkang mangkuk, cangkang tempayan, pagar kebun, jemuran, pante (tempat menjemur padi), jembatan dan rebung untuk dikonsumsi.

\section{Saran}

Jenis-jenis bambu yang di manfaatkan oleh masyarakat perlu adanya budidaya supaya tetap lestari, sehingga dapat menambah perekonomian masyarakat dengan menjual hasil-hasil kerajinan dari bambu tersebut dan perlu adanya peran dari pemerintah setempat yang menaungi masyarakat untuk dapat memberikan wadah dalam melakukan kegiatan menganyam kerajinan.

\section{DAFTAR PUSTAKA}

Berlian N, Rahayu E. 1995. Jenis Dan Prospek Bisnis Bambu. Jakarta. Penebar Swadaya.
Hartanto L. 2011. Seri Buku Informasi dan Potensi Pengelolaan Bambu Taman Nasional Alas Purwo. Banyuwangi: TNAP (Taman Nasional Alas Purwo)Press.

Jong Y, Wardenaar E, Tavita GE. 2018. Studi jenis dan pemanfaatan bambu oleh masyarakat Dusun Perigi Desa Semade Kecamatan Banyuke Hulu Kabupaten Landak. Jurnal Hutan Lestari. 6(1):131-136.

Junisa, Oramahi HA, Tavita GE. 2019. Studi pemanfaatan jenis bambu oleh masyarakat Dayak Bakati di hutan adat Desa Tanjung Kecamatan Teriak Kabupaten Bengkayang. Jurnal Hutan Lestari. 7(3):14241433.

Sary N, Fahrizal, Yani A. 2018. Jenis bambu di hutan tembawang Desa Suka Maju Kecamatan Sungai Betung Kabupaten Bengkayang. Jurnal Hutan Lestari. 6 (3): 637 646.

Sinyo Y, Sirajudin N, Hasan S. 2017. Pemanfaatan tumbuhan bambu : kajian empiris etnoekologi pada masyarakat kota Tidore Kepulauan. Jurnal Saintifik@. 1(2):57-69

Widjaja EA. 2001. Identikit Jenis-jenis Bambu di Jawa. Pusat Penelitian dan Bogor. Pengembangan BiologiLIPI Balai Penelitian Botani, Herbarium Bogoriense Bogor, Indonesia.

Widnyana K. 2012. Bambu Dengan berbagai manfaatnya. Bumi Lestari Journal of Environment Vol.8:1-10

Yani AP. 2012. Keanekaragaman dan populasi bambu di Desa Talang Pauh Bengkulu Tengah. Jurnal Exacta. 10(1):61-70. 